\title{
A hybrid unsupervised learning and multi-criteria decision making approach for performance evaluation of Indian banks
}

\author{
Soumendra Laha ${ }^{a}$ and Sanjib Biswas ${ }^{b^{*}}$
}

${ }^{a}$ St. Xavier's College (Autonomous), 30, Mother Teresa Sarani, Kolkata-700016, India

${ }^{b}$ Calcutta Business School, Diamond Harbour Road, Bishnupur - 743503, 24 Parganas (South), West Bengal, India

\section{H R O N I C L E}

Article history:

Received August 31, 2018

Received in revised format

October 232018

Accepted November 82018

Available online

November 82018

Keywords:

Multi-Criteria Decision Making

(MCDM)

Entropy

Combinative Distance-based

Assessment (CODAS)

$k$-Means Clustering

Performance

Indian Banks

\section{A B S T R A C T}

Efficient and stable performance of the banking system underpins sustainable growth of any economy. Of late, several economic reforms have been initiated in India for facilitating growth and withstanding dynamics of global economy. In this context, the current study compares the performance of the selected private and public sector banks in India on a five year time horizon in order to discern any changes in the performance over a period of time. First, the performance of the selected banks are examined in terms of management efficiency perspective using a MultiCriteria Decision Making (MCDM) technique such as Combinative Distance-based Assessment (CODAS) when an Entropy method is also employed for determining criteria weight. The study also applies k-Means Clustering for checking consistency of performance based ranking with asset management efficiency. Finally, the paper delves into the relationship between financial and market performance. The study has found consistent results and observed private sector banks perform better than the public sector.

\section{Introduction}

Banks are playing key role in any economy. Stability in the banking system and sustainable performance of banks not only maintains optimum utilization of financial resources, but also ensures effective financial flow across the components of the economy. Hence, banks are instrumental in economic growth and inclusive development of any country. The Indian economy has witnessed continuous reform and structural changes starting from early 90's. Alongside the world, economy has also encountered several changes. Recent past incidents like the bankruptcy of Lehman Brothers in 2008 leading to the global economic crisis, Brexit, devaluation of yuan, Greece debt crisis, a rise in US debt, slump in Japanese economy due to natural calamity, continuous war against terrorism, to name a few, have significantly impacted the world economy. In India, we have seen some major reforms like demonetization, the emergence of the digital economy, GST in the last few years. The banking sector in India consists of mainly two types of ownership groups: Public and Private (Domestic and Foreign). In addition, there are regional rural banks, urban and rural cooperative banks. In the sense, the Indian

* Corresponding author.

E-mail address: sanjibb@acm.org; sanjibb@calcuttabusinessschool.org (S. Biswas) 
banking sector is a complex system regulated by RBI. Though, the banks are controlled by regulatory norms, owing to the dynamic global economic environment and varying requirements by other components of the economy, performance of banks are not homogeneous. Though recent studies related to credit, market and liquidity risk have noted the resilient nature of the Indian banking system by its inherent system to withstand global economic turbulence, but, it is imperative to study bank performance for ensuring sustained profitability while minimizing risk. Hence, this area has always attracted the researchers and practitioners. Moreover, as India is growing at a considerable pace, it necessitates a comparative study of private and public sector banks in India.

Over the years, there has been a plethora of research being conducted on assessment of banking performance. Way back Beaver $(1966,1968)$ and Altman (1968) worked on performance assessment of banks in the context of bankruptcy prediction where they used financial ratios for their analysis. The study of Kwan and Eisenbeis (1997) reported asset quality is a useful indicator of risk and capitalization which determine the efficiency of operation of financial institutions. In tune with the work of Altman (1968) proposing a Z-score model for banks, Maishanu (2004) assessed financial health of banks using ratios while Mous (2005) attempted to predict bankruptcy through a comparative study using decision tree model and multiple discriminant models wherein the author reported better result for decision tree model.

CAMEL approach has been a widely accepted framework for assessing relative financial performance of banks while unfolding areas to improve. CAMEL approach incorporates parameters like Capital Adequacy, Assets Quality, Management Efficiency, Earnings Quality and Liquidity. In essence, it provides a broader outlook of bank performance. Based on the recommendation of Padmanabham Working Group (1995) committee, in 1996, RBI has adopted this framework. The CAMEL framework covers different aspects of bank performance reflected through a significant number of ratios. It has been a popular approach for evaluating bank performance and recommending measures for bank stability (Ayadi et al., 1998; Said \& Saucier, 2003; Sarker, 2005; Gupta \& Kaur, 2008; Hays et al., 2009; Maliszewski, 2009; Njoku, 2011; Klomp \& de Haan, 2011; Bhattacharyay, 2011; Njoku \& Inanga, 2012; Dash \& Das, 2013; Sayed \& Sayed, 2013; Popovska, 2014).

However, it is noteworthy that, Multi-Criteria Decision Making (MCDM) approaches have emerged as a growing stream of the literature, which has been applied by several researchers for assessing bank performance (Doumpos \& Zopounidis, 2015). MCDM techniques are well applied in solving complex economic decision making problems, and improving robustness of financial analysis (Balzentis et al., 2012). The literature is rife with applications of a variety of MCDM methods and techniques for understanding and ranking performance of banks. The following table (Table 1) summarizes some of work in the stated field using various MCDM techniques.

Data Envelopment Analysis (DEA) has been a widely used for risk measurement and monitoring and assessment and ranking of banking based on performance by measuring the efficiency of banking operations based on the parameters like labor, capital and deposits of the banks (input); credits, other earnings assets, and off-balance sheet activities (output). There are three broad streams of research observed in the literature. Research belong to first stream focus on assessing bank performance using financial statement based ratios related to CAMEL framework like return on assets (ROA), return on equity (ROE), net interest margin (NIM), return on investments (ROI), debt-equity ratio, capital adequacy ratio, total advances to total deposit ratio, return on net worth etc. The second stream evaluates the banks from the perspective of balanced scorecard measures (Kaplan and Norton, 1996). In this case, researchers have considered financial position, internal process efficiency, customer satisfaction room for learning and development of internal stakeholders such as employees. Here lies the linkage with the third stream, which focuses on customer satisfaction through superior service quality. The above mentioned MCDM techniques have been applied by the researchers on three major dimensions for assessing performance of banks and comparative analysis thereof. However, in this context, Datta Chaudhuri and Ghosh (2015) followed a different approach. They combined regulatory 
perspectives, risk parameters and market perception while evaluating the performance of selected private sector and public sector banks in India by using a hybrid MCDM framework.

\section{Table 1}

MCDM techniques used in evaluating bank performance

\begin{tabular}{|c|c|}
\hline MCDM Approaches & Author(s) \\
\hline $\begin{array}{l}\text { Data Envelopment Analysis } \\
\text { (DEA) }\end{array}$ & $\begin{array}{l}\text { De Young (1998); Kumar and Ravi (2007); Poghosyan and Cihak (2011); Halkos } \\
\text { and Salamouris (2004); Kao and Liu (2004); Ho and Wu (2009); Avkiran (2010); } \\
\text { Fallah et al. (2011); Dash and Charles (2012); Minh et al. (2013); Abbott et al. } \\
\text { (2013); Grigoroudis et al. (2013); Marie et al. (2013); Doumpos and Zopounidis } \\
\text { (2013); Dash and Vegesna (2014); Bayyurt (2013) }\end{array}$ \\
\hline TOPSIS/ Fuzzy-TOPSIS & $\begin{array}{l}\text { Wu et al. (2009); Pal and Choudhury (2009); Önder and Hepşen (2013); Amile et } \\
\text { al. (2013); Amirzadeh and Shoorvarzi (2013); Toloie-Eshlaghy et al. (2011); } \\
\text { Bayyurt (2013); Datta Chaudhuri and Ghosh (2015); Celen (2014); Momeni (2011); } \\
\text { Akkoç and Vatansever (2013) }\end{array}$ \\
\hline VIKOR & Datta Chaudhuri and Ghosh (2015); Momeni (2011); \\
\hline ELECTRE & Datta Chaudhuri and Ghosh (2015); Bayyurt (2013); \\
\hline AHP/ Fuzzy-AHP & $\begin{array}{l}\text { Stankevičienè and Mencaite (2012); Önder and Hepşen (2013); Albayrak and } \\
\text { Erensal (2005); Wu et al. (2009); Chatterjee et al. (2010); Shaverdi et al. (2011); } \\
\text { Celen (2014); Akkoç and Vatansever (2013) }\end{array}$ \\
\hline COPRAS & Ginevičius and Podviezko (2013) \\
\hline SAW & Momeni (2011); \\
\hline ANP & Dinçer et al. (2016) \\
\hline
\end{tabular}

In this study, we have adopted an integrated approach in assessing performance of selected public and private sector bank. We have applied Combinative Distance-based Assessment (CODAS) approach for understanding their comparative performance. As it is evident from table 1 that TOPSIS has been widely applied by the researchers. CODAS is a relatively new MCDM method, which considers the relative importance of distances from positive ideal solution (PIS) and negative ideal solution (NIS) unlike TOPSIS. We have used K-means clustering for grouping the banks based on their asset management efficiency specially NPA management. Finally, we have investigated whether better performance of banks lead to better standing in the market or not.

The rest of the paper is organized as follows. Section 2 discusses about the research methodology followed in this study while section 3 highlights the results of our analysis. In section 4, the findings are elaborated. Section 5 highlights some limitations and future scope of research. Finally, section 6 concludes the study.

\section{Data and methodology}

As it is mentioned in section 1, in this study we plan to assess the performance of the selected Indian public and private sector banks. The period of study is from financial year 2012-13 to financial year 2016-17, that is, 5 years. Broadly, this study aims to address the questions like: To what extent banks are different as far as performance is concerned? Are private banks superior in performance than their public sector counterparts? Are better performers efficient in recovering their advance, i.e. recovering NPAs? Does better financial performance reflect in market performance?

In order to address these questions, this study first presents a financial performance based ranking of the selected private and public sector banks using CODAS method. However, over the last few years, Non Performing Assets (NPA) have undermined the growth of the banking sector in India. Narasimham Committee II (1998) remarked,

"NPAs constitute a real economic cost to the nation is that they reflect the application of scarce capital $\&$ credit funds to unproductive uses. The money locked up in NPAs is not available for productive uses to the extent that bank seek to make provisions for NPAs or write them off. It is a charge on their profits, NPAs, in short, is not just a problem for banks; they are bad for the economy". Financial ratios may not always give a true picture for two reasons: the banks are regulated by the policies set by the 
Reserve Bank of India (RBI) and provisions for NPAs. Thus, in the second step, we have applied clustering method to check whether the banks are efficient enough to handle NPA. Our contention is that financially well performer is likely to belong to the efficient cluster. Thus, in this way we validate our MCDM based ranking. However, it is also likely that financially well performer is equally good at market measure. To check this proposition, we further have considered year wise price to book value ( $\mathrm{P} / \mathrm{B}$ ratio) for all the banks under study. The banks are ranked according to $\mathrm{P} / \mathrm{B}$ ratio and get checked with financial performance based ranking. Also, their stock performance over last five financial year is analyzed. In essence, this study presents an integrated three-stage framework wherein the focus is put on checking financial performance, efficiency in handling NPA and market performance. Fig. 1 depicts the flow of the steps being followed in this study for analyzing bank performance.

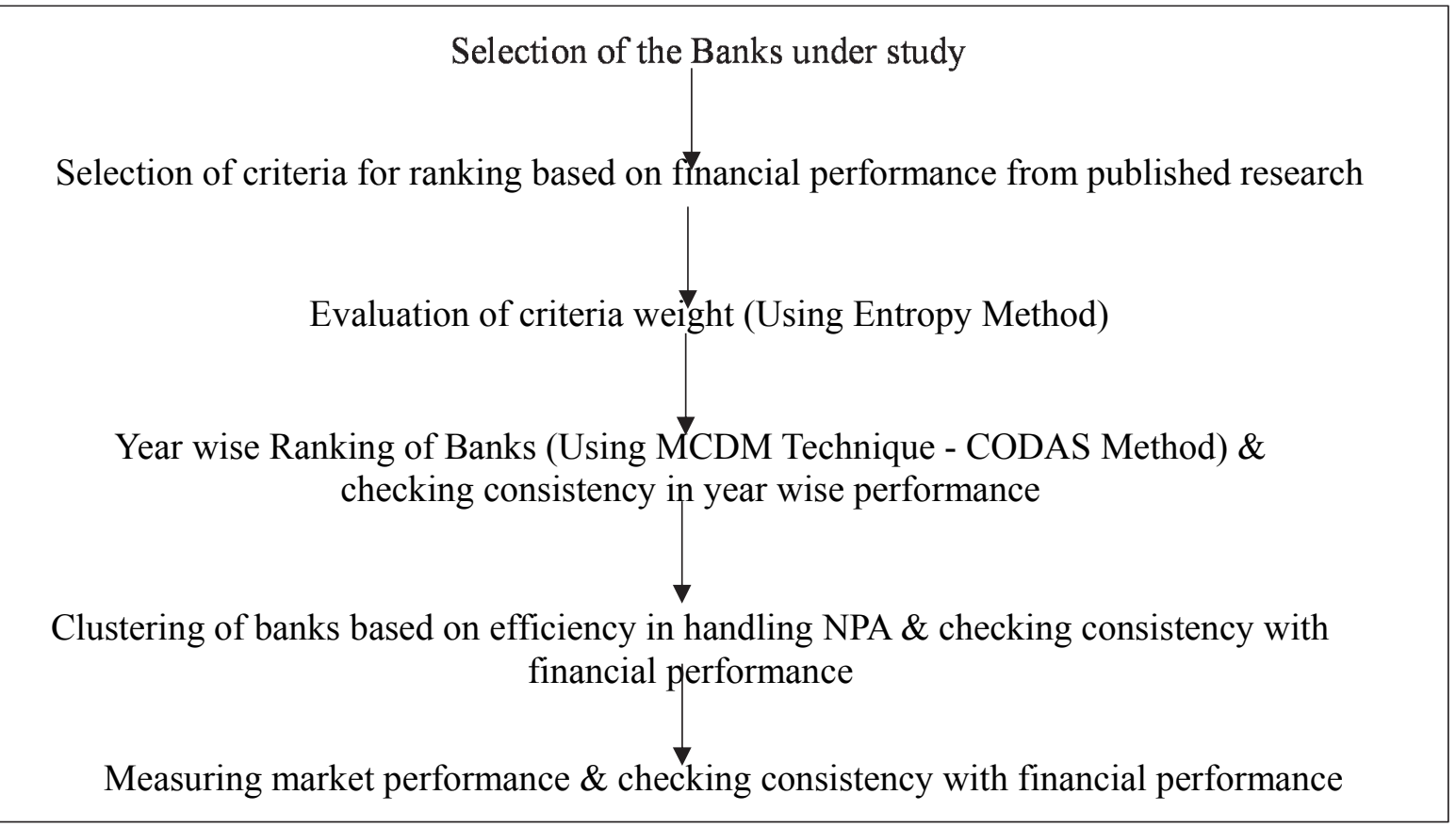

\subsection{Sample}

Fig. 1. Stepwise analysis scheme followed in this study (Source: Authors)

In order to select the banks under study, we considered both the sector: public and private, operating in India. On the basis of market capitalization (as reported by Moneycontrol, a leading financial information source in India), we have considered five leading banks from each category.

Table 2

Name of banks under study

\begin{tabular}{clcc}
\hline Alternative Number & \multicolumn{1}{c}{ Name of the banks } & Abbreviation & Sector \\
\hline A1 & HDFC Bank & HDFC & Private \\
A2 & ICICI Bank & ICICI & Private \\
A3 & Axis Bank & Axis & Private \\
A4 & State Bank of India & SBI & Public \\
A5 & Bank of Baroda & BOB & Public \\
A6 & Canara Bank & IB & Public \\
A7 & IndusInd Bank & KMB & Private \\
A8 & Kotak Mahindra Bank & IDBI & Private \\
A9 & IDBI Bank & PNB & Public \\
A10 & Punjab National Bank & Public \\
\hline
\end{tabular}

Table 2 lists the names of the banks selected under study. In this study data have been collected from secondary sources such as annual reports of the banks, financial statements and Basel Disclosures of 
the banks, and websites like BSE, Moneycontrol, Valueresearchonline, Morningstar for the financial years 2012-13; 2013-14; 2014-15; 2015-16 and 2016-17.

\subsection{Selection of Variables}

Gowri and Malepati (2017) worked on management efficiency based ratios to compare public sector and private sector banks. In our study, for applying MCDM framework we have referred their study. However, Gowri and Malepati (2017) used gross profit to total assets and net profit to total assets ratios which in our study we have not considered. Due to some imposed regulations and nature of operations, banks need to maintain certain provisions. We contend that the above stated two ratios may not properly indicate management efficiency. Instead, we have used the ratio such as Profit before Provisions to Total Funds. Table 3 lists out the ratios which are used in this study as criteria for ranking the sample banks using MCDM technique.

Table 3

Criteria used for ranking sample banks using MCDM technique

\begin{tabular}{cll}
\hline Criterion & & \multicolumn{1}{c}{ Description } \\
\hline C1 & Profit Before Provisions / Total Funds & Higher the Better \\
C2 & Interest Income to Total Assets Ratio & Higher the Better \\
C3 & Net Interest Income (i.e. Interest earned-interest expended) to Total Assets & Higher the Better \\
C4 & Other Income to TA & Higher the Better \\
C5 & Interest Expended/TA & Lower the better \\
C6 & Operating Expense/TA & Lower the better \\
\hline
\end{tabular}

Asset quality plays a central role in facilitating efficient banking operation and fostering sustainable growth. Asset quality acts as a good indicator of the nature of the debtors and the status of nonPerforming Assets (NPA) as a percentage of the total assets. Of late, NPA has been a serious concern for the banking sector. NPA signifies credit risk since it reflects non-performance of recovery of loans and advances, and portfolio management. Presence of NPA affects effective recycling of funds; reduces income interest and decrease profit margin by including provisions. This leads to substantial weakening of capital base and in the long run loss of competitiveness. However, lending is an inevitable function of any bank. Thus, NPA is inherited in the system. The challenge lies in keeping the level of NPA below the affordable limit. There are several macro-economic and internal factors behind the generation of NPA. Internal factors like inefficient portfolio management, poor credit planning, assessment and monitoring, and lack of effective governance stand responsible for building up NPA levels beyond tolerable limits (Samir \& Kamra, 2013). The presence of the NPA in percentage of gross and net advances moderates net worth performance. Efficiency in banking operations is reflected in managing NPA. Therefore, in our study, we have considered mean gross NPA to total advance ratio over the period of study as the basis of clustering. Accordingly, banks are classified under three categories: efficient, average and poor in relation to their NPA management efficiency. Ceteris paribus, lower value of this ratio indicates that the corresponding bank has an efficient NPA recovery process and effective management of the loan portfolio. In other words, loosely we can say management is efficient. Therefore, this clustering in a sense validates our findings of performance based ranking using CODAS method.

In order to understand the market performance of the banks under study, we have further considered Price to Book Value ratio (PB ratio). This ratio is broadly described as a ratio of price per share to book value per share over a defined period. Book value signifies how valuable a company is. There are umpteen research on analyzing PB ratio and its significance. Studies (Foster, 1970; Fairfield, 1994; Penman, 1996; Ohlson, 2001) reported that PB ratio or PB multiple is significantly associated with the future equity value i.e. in other words stock performance. Lower PB ratio value (especially below 1) signifies either the market opines the asset value is overstated, i.e. the stock is undervalued or, fundamentally there is something wrong with the company, i.e. return on asset (ROA) for the company is very poor (even negative). In essence, the higher PB ratio specifies acceptance of the respective company by the investors, i.e. a better market performance. In our study, we have ranked the banks 
based on PB ratio year wise and subsequently checked its consistency with year wise financial performance based ranks. Further, we have considered 5 Yr. average PB ratio based ranking of the sample banks and checking its consistency with current PB ratio based rank. Since PB ratio is associated with stock performance, we have also carried out an analysis of stock price movements of the banks under study. Table 4 to Table 8 present year wise descriptive statistics of the banks based on performance parameters.

Table 4

Descriptive Statistics (Fy 2016-17)

\begin{tabular}{lccccccc}
\hline Criteria & $2016-17$ & C1 & C2 & C3 & C4 & C5 & C6 \\
\hline Banks under study & A1 & 3.270000 & 0.060876 & 0.037000 & 0.014235 & 0.041867 & 0.022809 \\
& A2 & 3.560000 & 0.051956 & 0.022000 & 0.025272 & 0.042005 & 0.019118 \\
& A3 & 3.120000 & 0.055911 & 0.030000 & 0.019438 & 0.043974 & 0.020284 \\
& A4 & 2.060000 & 0.044813 & 0.003000 & 0.013105 & 0.042003 & 0.017174 \\
& A5 & 1.610000 & 0.042475 & 0.021000 & 0.009726 & 0.041283 & 0.013379 \\
& A6 & 1.580000 & 0.052019 & 0.017000 & 0.012946 & 0.054010 & 0.014588 \\
& A7 & 3.430000 & 0.066107 & 0.033936 & 0.023350 & 0.046701 & 0.026774 \\
& A8 & 2.940000 & 0.063472 & 0.037868 & 0.016204 & 0.044610 & 0.026182 \\
& A9 & 1.260000 & 0.054641 & 0.015899 & 0.010967 & 0.060922 & 0.014210 \\
& A10 & 2.110000 & 0.047635 & 0.020814 & 0.012427 & 0.044817 & 0.013021 \\
\hline
\end{tabular}

Table 5

Descriptive Statistics (Fy 2015-16)

\begin{tabular}{cccccccc}
\hline & $2015-16$ & & & & & & \\
Criteria & & C1 & C2 & C3 & C4 & C5 & C6 \\
\hline Banks under study & A1 & 3.290000 & 0.063751 & 0.038000 & 0.015168 & 0.046032 & 0.023954 \\
& A2 & 3.500000 & 0.054255 & 0.023000 & 0.021261 & 0.043729 & 0.017599 \\
& A3 & 3.260000 & 0.057731 & 0.032000 & 0.017835 & 0.045969 & 0.019223 \\
& A4 & 2.010000 & 0.051476 & 0.005000 & 0.012465 & 0.047278 & 0.018495 \\
& A5 & 1.270000 & 0.046326 & 0.020000 & 0.007446 & 0.046653 & 0.013291 \\
& A6 & 1.310000 & 0.058335 & 0.018000 & 0.008817 & 0.061955 & 0.013549 \\
& A7 & 3.330000 & 0.068922 & 0.032248 & 0.023540 & 0.050437 & 0.026219 \\
& A8 & 2.710000 & 0.065345 & 0.035891 & 0.013587 & 0.049328 & 0.028459 \\
A9 & 1.490000 & 0.055611 & 0.016265 & 0.009110 & 0.058642 & 0.011031 \\
& A10 & 1.930000 & 0.052707 & 0.022943 & 0.010304 & 0.048117 & 0.014942 \\
\hline
\end{tabular}

Table 6

Descriptive Statistics (Fy 2014-15)

\begin{tabular}{cccccccc}
\hline & & & & & & \\
Criteria & $2014-15$ & $\mathrm{C} 1$ & $\mathrm{C} 2$ & $\mathrm{C} 3$ & $\mathrm{C} 4$ & $\mathrm{C} 5$ & $\mathrm{C} 6$ \\
\hline Banks under study & A1 & 3.220000 & 0.063840 & 0.037000 & 0.015235 & 0.044156 & 0.023687 \\
& A2 & 3.180000 & 0.055447 & 0.023000 & 0.018845 & 0.046510 & 0.017792 \\
& A3 & 3.170000 & 0.056500 & 0.030000 & 0.018109 & 0.046012 & 0.019924 \\
& A4 & 2.030000 & 0.055100 & 0.008000 & 0.011023 & 0.047548 & 0.018885 \\
& A5 & 1.440000 & 0.045249 & 0.020000 & 0.006157 & 0.041646 & 0.010733 \\
& A6 & 1.350000 & 0.059901 & 0.018000 & 0.008303 & 0.062201 & 0.013255 \\
& A7 & 3.170000 & 0.073263 & 0.031345 & 0.022030 & 0.057477 & 0.024982 \\
& A8 & 3.100000 & 0.070678 & 0.039842 & 0.019134 & 0.051844 & 0.030702 \\
& A9 & 1.680000 & 0.058700 & 0.016144 & 0.011256 & 0.062933 & 0.011312 \\
& A10 & 2.080000 & 0.058718 & 0.027440 & 0.009764 & 0.049326 & 0.017389 \\
\hline
\end{tabular}


Table 7

Descriptive Statistics (Fy 2013-14)

\begin{tabular}{cccccccc}
\hline Criteria & $2013-14$ & & & & & & \\
& & C1 & C2 & C3 & C4 & C5 & C6 \\
\hline Banks under study & A1 & 3.220000 & 0.065181 & 0.030000 & 0.016110 & 0.046080 & 0.024496 \\
& A2 & 2.930000 & 0.053188 & 0.022000 & 0.017536 & 0.046587 & 0.017336 \\
& A3 & 3.170000 & 0.057710 & 0.031000 & 0.019322 & 0.048767 & 0.020615 \\
& A4 & 1.910000 & 0.057411 & 0.008000 & 0.010352 & 0.048581 & 0.019934 \\
& A5 & 1.540000 & 0.044597 & 0.019000 & 0.006767 & 0.040901 & 0.010822 \\
& A6 & 1.520000 & 0.059335 & 0.018000 & 0.007995 & 0.062211 & 0.012362 \\
& A7 & 3.250000 & 0.077860 & 0.033217 & 0.021724 & 0.061623 & 0.025111 \\
& A8 & 3.010000 & 0.076520 & 0.042473 & 0.015981 & 0.057625 & 0.029030 \\
& A9 & 1.750000 & 0.061887 & 0.018303 & 0.009054 & 0.062542 & 0.010088 \\
& A10 & 2.220000 & 0.059510 & 0.029334 & 0.008315 & 0.049194 & 0.016966 \\
\hline
\end{tabular}

Table 7

Descriptive Statistics (Fy 2012-13)

\begin{tabular}{cccccccc}
\hline & & & & & & \\
Criteria & $2012-13$ & C1 & C2 & C3 & C4 & C5 & C6 \\
\hline Banks under study & A1 & 3.100000 & 0.067704 & 0.031000 & 0.017117 & 0.048094 & 0.028067 \\
& A2 & 2.610000 & 0.051946 & 0.021000 & 0.015547 & 0.048825 & 0.016790 \\
& A3 & 2.970000 & 0.056605 & 0.028000 & 0.019236 & 0.051434 & 0.020303 \\
& A4 & 2.140000 & 0.058153 & 0.009000 & 0.010238 & 0.048093 & 0.018697 \\
& A5 & 1.810000 & 0.049915 & 0.021000 & 0.006636 & 0.043648 & 0.010869 \\
& A6 & 1.510000 & 0.060545 & 0.019000 & 0.007647 & 0.063537 & 0.012470 \\
& A7 & 2.820000 & 0.077698 & 0.030459 & 0.018593 & 0.064801 & 0.023959 \\
& A8 & 3.010000 & 0.073726 & 0.038302 & 0.013868 & 0.057792 & 0.026403 \\
& A9 & 1.790000 & 0.061051 & 0.016647 & 0.009975 & 0.061007 & 0.009711 \\
& A10 & 2.340000 & 0.067198 & 0.031024 & 0.008804 & 0.056459 & 0.017050 \\
\hline
\end{tabular}

\subsection{Methods}

\subsubsection{Determination of Criteria Weight - Entropy Method}

The entropy method determines criteria weight based on relative information (Shannon, 1948). According to this method, higher the entropy value, more the criterion contains information. The steps (Li et al., 2011) are given below:

Suppose,

$a_{i}: i^{\text {th }}$ alternative where $\mathrm{i}=1,2,3, \ldots . . \mathrm{m}$

$c_{j}: \mathrm{j}^{\text {th }}$ criterion where $\mathrm{j}=1,2,3, \ldots \ldots \mathrm{n}$

$x_{i j}: \mathrm{j}^{\text {th }}$ criterion value for the $\mathrm{i}^{\text {th }}$ alternative

Step1: Standardization of Criteria

This is done in order to eliminate the influence of criteria on the alternatives.

Standardized value of $x_{i j}$ is given by:

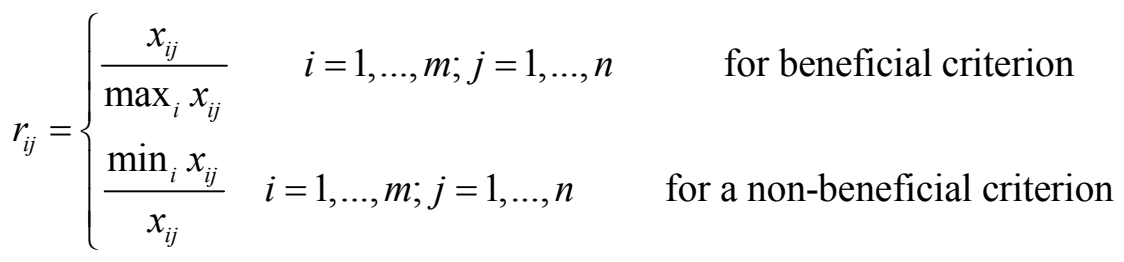


After this process, we get a standardized criteria matrix $R=\left[r_{i j}\right]_{m \times n}$

Step 2: Calculation of the criterion's entropy

Entropy of the $\mathrm{j}^{\text {th }}$ criterion is given by:

$$
H_{j}=-\frac{\sum_{i=1}^{m} f_{i j} \ln f_{i j}}{\ln m}, i=1,2, \ldots m ; j=1,2, \ldots n
$$

where,

$$
f_{i j}=\frac{r_{i j}}{\sum_{i}^{m} r_{i j}}, i=1,2, \ldots m ; j=1,2, \ldots n
$$

Step 3: Calculation of the criterion's entropy weight

Entropy weight of the $\mathrm{j}^{\text {th }}$ criterion is determined by:

$$
w_{j}=\frac{1-H_{j}}{n-\sum_{j=1}^{n} H_{j}}, \text { where } \sum_{j=1}^{n} w_{j}=1
$$

\subsubsection{Ranking of Banks - CODAS Method}

Combinative distance-based assessment (CODAS) method is a relatively new MCDM technique. Unlike the TOPSIS method, a popular distance based MCDM technique, which has been used by many researchers; CODAS method incorporates the relative importance of distances from positive ideal solution (PIS) and negative ideal solution (NIS). Ghorabaee et al. (2016) explained this method and presented its comparative analysis with other MCDM techniques. CODAS method evaluates the alternatives based on a combination of two distance measures such as the Euclidean (used as a primary measure related to $1^{2}$-norm indifference space) and Taxicab distances (used as a secondary measure related to $1^{1}$-norm indifference space) from the negative ideal solution (NIS). In this method if the Euclidean distances of the two alternatives are in proximity to each other (the degree of closeness is being controlled by a threshold parameter), comparison is carried out using the Taxicab distance. The alternative that has greater distances from NIS is considered best among the others. The steps are given below.

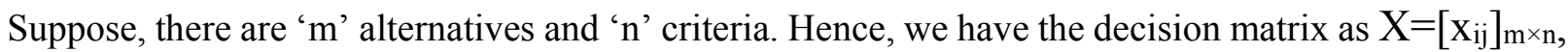
where, $x_{i j}: \mathrm{j}^{\text {th }}$ criterion value for the $\mathrm{i}^{\text {th }}$ alternative. $(\mathrm{i}=1,2, \ldots \mathrm{m} ; \mathrm{j}=1,2, \ldots \mathrm{n})$

Step 1: Normalization of the decision matrix

Linear normalization of $x_{i j}$ values are given by

$$
r_{i j}= \begin{cases}\frac{x_{i j}}{\max x_{i j}} & \text { if } j \text { is a beneficial criterion } \\ \frac{i}{\min x_{i j}} & \text { if } j \text { is a non-beneficial criterion }\end{cases}
$$

Step 2: Formation of weighted normalized decision matrix

Weighted normalized decision matrix is given by

$r_{i j}^{*}=w_{j} r_{i j} ;$ where $w_{j}$ denotes the weight of the $\mathrm{j}^{\text {th }}$ criterion. $\left(\sum_{j=1}^{n} w_{j}=1\right)$ 
Step 3: Determination of NIS

$$
\begin{aligned}
& n s=\left[n s_{j}\right]_{1 \times n} \\
& n s_{j}=\min _{i} r_{i j}^{*}
\end{aligned}
$$

Step 4: Calculation of Euclidean $\left(\mathrm{E}_{\mathrm{i}}\right)$ and Taxicab $\left(\mathrm{T}_{\mathrm{i}}\right)$ distances of the alternatives from NIS

$$
\begin{aligned}
E_{i} & =\sqrt{\sum_{j=1}^{n}\left(r_{i j}^{*}-n s_{j}\right)^{2}} \\
T_{i} & =\sum_{j=1}^{n}\left|r_{i j}^{*}-n s_{j}\right|
\end{aligned}
$$

Step 5: Construction of relative assessment matrix $(\mathrm{R})$

$$
\begin{aligned}
& R=\left[h_{i k}\right]_{m \times m} \\
& h_{i k}=\left(E_{i}-E_{k}\right)+\left(\psi\left(E_{i}-E_{k}\right) \times\left(T_{i}-T_{k}\right)\right)
\end{aligned}
$$

where, $\mathrm{k}=1,2, \ldots \mathrm{m} ; \psi$ denotes a threshold function which indicates the equality of the Euclidean distances of two alternatives as

$$
\psi(x)=1, \text { if }\lceil x\rceil \geq \tau ; 0, \text { otherwise }
$$

$x$ is the difference between Euclidean distances of the two alternatives and $\tau$ is a threshold parameter which determines the use of distance measure. In this study, we have taken its value as 0.02

Step 6: Calculation of assessment score $\left(\mathrm{H}_{\mathrm{i}}\right)$ and ranking of alternatives

$$
H_{i}=\sum_{k=1}^{m} h_{i k}
$$

The alternative, which gets highest $H_{i}$ would be ranked first and so on.

\subsubsection{K-Means Clustering}

Clustering is done in order to divide a set of data points into a specific number of disjoint groups. There are various methods of clustering. Standard k-Means Clustering or k-Means Clustering is a well-known method wherein the data points are partitioned into ' $\mathrm{k}$ ' groups or clusters. The mechanism can be explained by following broad steps (Faber, 1994):

\section{Steps:}

i. Calculation of $\mathrm{k}$ centroids

ii. Distribution of data points to a particular cluster, where the data points are having least distance from the centroid of that group. For distance calculation, Euclidean distance is commonly used.

iii. Repeat calculation of centroid of each cluster and distance of all data points from each such different centroid and reformation of clusters.

iv. Each disjoint cluster is featured by its centroid and member data points or objects. Centroid of a cluster is a point from which sum of the distances of each member of that cluster is minimum. Repeat the process until the sum of distances from each object to its cluster centroid, over all clusters is minimized. 


\section{Results}

For analysis purpose, we have used Microsoft Excel (2013 version) and IBM SPSS (version 20). Table 9 and 10 describes the results of determination of criteria weights using entropy method.

Table 9

Standardization Table (R-Matrix)

\begin{tabular}{ccccccc}
\hline & $\mathrm{C} 1$ & $\mathrm{C} 2$ & $\mathrm{C} 3$ & $\mathrm{C} 4$ & $\mathrm{C} 5$ & $\mathrm{C} 6$ \\
\hline A1 & 0.91854 & 0.92087 & 0.97707 & 0.56327 & 0.98604 & 0.57087 \\
A2 & 1 & 0.78593 & 0.58096 & 1 & 0.98282 & 0.68108 \\
A3 & 0.8764 & 0.84577 & 0.79222 & 0.76916 & 0.9388 & 0.64195 \\
A4 & 0.57865 & 0.67789 & 0.07922 & 0.51855 & 0.98286 & 0.75817 \\
A5 & 0.45225 & 0.64252 & 0.55455 & 0.38484 & 1 & 0.97327 \\
A6 & 0.44382 & 0.78688 & 0.44892 & 0.51228 & 0.76436 & 0.89259 \\
A7 & 0.96348 & 1 & 0.89616 & 0.92397 & 0.88398 & 0.48633 \\
A8 & 0.82584 & 0.96014 & 1 & 0.64118 & 0.92543 & 0.49731 \\
A9 & 0.35393 & 0.82654 & 0.41984 & 0.43397 & 0.67763 & 0.91631 \\
\hline A10 & 0.5927 & 0.72057 & 0.54965 & 0.49173 & 0.92115 & 1 \\
\hline
\end{tabular}

Table 10

Criteria Weight

\begin{tabular}{ccccccc}
\hline Criterion & C1 & C2 & C3 & C4 & C5 & C6 \\
\hline H-value & 0.9757 & 0.99587 & 0.95105 & 0.97925 & 0.99718 & 0.98631 \\
Weight (w) & 0.21196 & 0.03602 & 0.42698 & 0.18103 & 0.02464 & 0.11938 \\
\hline (Source: Authors') own analysis) & & &
\end{tabular}

(Source: Authors' own analysis)

Table 11 shows year wise assessment score (Hi) and ranking of banks using CODAS method. Table 12 indicates year wise ranking of banks based on PB ratio.

Table 11

Year wise financial performance based ranking (CODAS method)

\begin{tabular}{ccccccccccc}
\hline & \multicolumn{2}{c}{ FY 2012-13 } & \multicolumn{2}{c}{ FY 2013-14 } & \multicolumn{2}{c}{ FY 2014-15 } & \multicolumn{2}{c}{ FY 2015-16 } & \multicolumn{2}{c}{ FY 2016-17 } \\
\cline { 2 - 11 } Bank & H & Rank & H & Rank & H & Rank & H & Rank & H & Rank \\
\hline A1 & 4.09007 & 2 & 2.6948 & 3 & 3.7525 & 2 & 4.3181 & 1 & 3.8166 & 3 \\
A2 & -0.65165 & 6 & -0.0801 & 5 & 0.4181 & 5 & 1.0546 & 5 & 1.2848 & 5 \\
A3 & 2.16678 & 4 & 2.5018 & 4 & 2.0463 & 4 & 2.5919 & 4 & 2.1956 & 4 \\
A4 & -3.31892 & 7 & -3.3819 & 7 & -3.7377 & 7 & -4.1903 & 9 & -5.0150 & 10 \\
A5 & -3.36888 & 8 & -3.8751 & 10 & -3.8766 & 10 & -3.2312 & 7 & -2.4275 & 7 \\
A6 & -3.53637 & 9 & -3.7081 & 9 & -3.7652 & 8 & -3.3579 & 8 & -2.9439 & 8 \\
A7 & 3.27015 & 3 & 4.1682 & 2 & 3.6790 & 3 & 4.3101 & 2 & 4.3575 & 1 \\
A8 & 4.82363 & 1 & 5.6812 & 1 & 5.8067 & 1 & 4.0967 & 3 & 4.1705 & 2 \\
A9 & -3.99989 & 10 & -3.6812 & 8 & -3.8233 & 9 & -3.9385 & 10 & -3.4407 & 9 \\
A10 & 0.52509 & 5 & -0.3197 & 6 & -0.4999 & 6 & -1.6535 & 6 & -1.9980 & 6 \\
\hline (Source: Authors' own analysis) & & & & & & & & & &
\end{tabular}

\section{Table 12}

Year wise ranking of banks based on PB ratio

\begin{tabular}{|c|c|c|c|c|c|c|c|}
\hline \multirow{2}{*}{ Bank } & \multicolumn{5}{|c|}{ Year wise Rank (Based on PB Ratio) } & \multirow{2}{*}{ Current Rank } & \multirow{2}{*}{$\frac{\mathrm{P} / \mathrm{B} \text { ratio based rank }}{5 \text { Years Avg }}$} \\
\hline & $2012-13$ & 2013-14 & 2014-15 & $2015-16$ & $2016-17$ & & \\
\hline A1 & 1 & 2 & 1 & 3 & 2 & 3 & 2 \\
\hline $\mathrm{A} 2$ & 4 & 5 & 5 & 5 & 5 & 5 & 5 \\
\hline A3 & 5 & 4 & 3 & 4 & 4 & 4 & 4 \\
\hline A4 & 6 & 6 & 6 & 6 & 6 & 7 & 6 \\
\hline A5 & 7 & 7 & 7 & 7 & 8 & 8 & 7 \\
\hline A6 & 9 & 9 & 10 & 10 & 10 & 9 & 10 \\
\hline A7 & 3 & 3 & 2 & 1 & 1 & 1 & 3 \\
\hline A8 & 2 & 1 & 4 & 2 & 3 & 2 & 1 \\
\hline A9 & 10 & 10 & 8 & 9 & 9 & 6 & 9 \\
\hline A10 & 8 & 8 & 9 & 8 & 7 & 10 & 8 \\
\hline
\end{tabular}

Table 13 to Table 15 show the result of k-means cluster analysis using IBM SPSS 20. 
Table 3

Initial Cluster Centers

\begin{tabular}{llll}
\hline & \multicolumn{3}{c}{ Cluster } \\
\cline { 2 - 4 } & 1 & 2 & 3 \\
\hline Mean_NPA_ADV_Ratio & .009579 & .061855 & .098771 \\
\hline
\end{tabular}

(Source: Authors' own analysis)

\section{Table 14}

Cluster Membership

\begin{tabular}{cccc}
\hline Case Number & Bank_Name & Cluster & Distance \\
\hline 1 & HDFC & 1 & .006 \\
2 & ICICI & 2 & .006 \\
3 & Axis & 1 & .007 \\
4 & SBI & 2 & .000 \\
5 & BOB & 2 & .005 \\
6 & CB & 2 & .001 \\
7 & IB & 1 & .006 \\
8 & KMB & 1 & .005 \\
9 & IDBI & 3 & .006 \\
\hline
\end{tabular}

(Source: Authors' own analysis)

Table 15

Final Cluster Centers

\begin{tabular}{llll}
\hline & \multicolumn{3}{c}{ Cluster } \\
\cline { 2 - 4 } & 1 & 2 & 3 \\
\hline Mean_NPA_ADV_Ratio & .015848 & .056672 & .092642 \\
\hline (Source: Authors' own analysis)
\end{tabular}

However, in order to check the statistical significance of the consistency between year wise performances based ranks; between performances based ranks and PB ratio based ranks, Spearman's Rank Correlation test has been performed. The correlation coefficient (Spearman's rho) is given by:

$\rho=1-\frac{6 \sum d_{i}^{2}}{n\left(n^{2}-1\right)}$,

where, $d_{i}$ is the difference between ranks of two different methods for $\mathrm{i}^{\text {th }}$ alternative and $\mathrm{n}$ is the number of alternatives. We have performed this test using SPSS 20 software. Tables 16-19 exhibit the findings.

Table 16

Correlation between year to year financial performance based ranks

\begin{tabular}{cccc}
\hline $2012-13 \& 2013-14$ & $2013-14 \& 2014-15$ & $2014-15 \& 2015-16$ & $2015-16 \& 2016-17$ \\
\hline 0.927 & 0.976 & 0.879 & 0.952 \\
\hline $\begin{array}{c}\text { Significant at } 0.01 \\
\text { level (2 tailed) }\end{array}$ & $\begin{array}{c}\text { Significant at } 0.01 \\
\text { level (2 tailed) }\end{array}$ & $\begin{array}{c}\text { Significant at } 0.01 \\
\text { level }(2 \text { tailed) }\end{array}$ & $\begin{array}{c}\text { Significant at } 0.01 \\
\text { level (2 tailed) }\end{array}$ \\
\hline (Source: Authors' own analysis) & & &
\end{tabular}

Table 17

Correlation between year wise performance based ranks \& PB ratio based ranks

\begin{tabular}{ccccc}
\hline $2012-13$ & $2013-14$ & $2014-15$ & $2015-16$ & $2016-17$ \\
\hline 0.891 & 0.879 & 0.782 & 0.855 & 0.855 \\
\hline $\begin{array}{c}\text { Significant at } 0.01 \text { level } \\
\text { (2 tailed) }\end{array}$ & $\begin{array}{c}\text { Significant at } 0.01 \text { level } \\
\text { (2 tailed) }\end{array}$ & $\begin{array}{c}\text { Significant at } 0.01 \text { level } \\
\text { (2 tailed) }\end{array}$ & $\begin{array}{c}\text { Significant at } 0.01 \text { level } \\
\text { (2 tailed) }\end{array}$ & $\begin{array}{c}\text { Significant at } 0.01 \text { level } \\
\text { (2 tailed) }\end{array}$ \\
\hline
\end{tabular}


Table 18

Correlation between year to year PB based ranks

\begin{tabular}{cccc}
\hline $2012-13 \& 2013-14$ & $2013-14 \& 2014-15$ & $2014-15 \& 2015-16$ & $2015-16 \& 2016-17$ \\
\hline 0.976 & 0.891 & 0.927 & 0.976 \\
\hline $\begin{array}{c}\text { Significant at 0.01 level (2 } \\
\text { tailed) }\end{array}$ & $\begin{array}{c}\text { Significant at 0.01 level (2 } \\
\text { tailed) }\end{array}$ & $\begin{array}{c}\text { Significant at 0.01 level (2 } \\
\text { tailed) }\end{array}$ & $\begin{array}{c}\text { Significant at 0.01 level (2 } \\
\text { tailed) }\end{array}$ \\
\hline $\begin{array}{l}\text { (Source: Authors' own analysis) } \\
\text { (Siled }\end{array}$ & & &
\end{tabular}

Table 19

Correlation between PB ratio based current ranks \& 5 years average ranks

\begin{tabular}{lll}
\hline Spearman's rho value & 0.876 & Significant at 0.01 level (2 tailed) \\
\hline (Source: Authors' own analysis) &
\end{tabular}

Fig. 2 presents the comparison of stock performances of the banks under study.
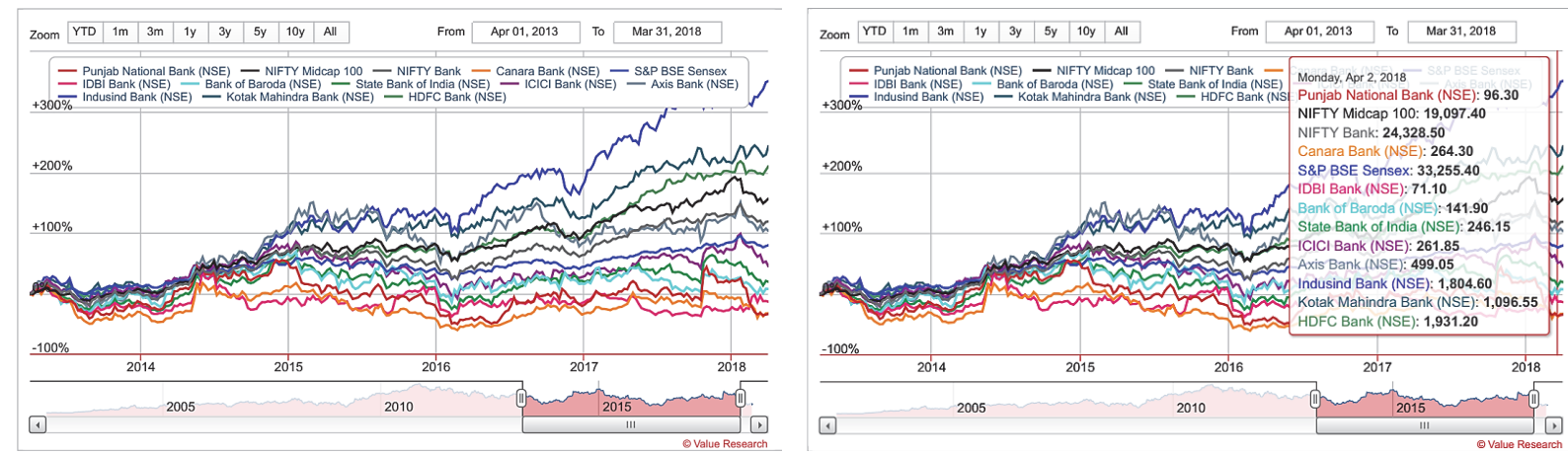

Fig. 2. The performance of the selected shares

Source: https://www.moneycontrol.com; retrieved on June 26, 2018

\section{Discussion}

This study lists out some significant observations. Firstly, we observe that year to year financial performance is consistent and statistically significant in nature (ref: Tables 16-18). We have noticed relatively high correlation values. It signifies that banks perform more or less in a similar manner during the period of study (2013-2017). However, Table 11 puts forth some interesting findings. We see private banks (A1-A3 and A7-A8) have performed relatively better than their public sector counterparts. IndusInd Bank, Kotak Mahindra Bank and HDFC bank consistently share top three positions while interestingly State Bank of India, IDBI bank and Bank of Baroda consistently remain at the bottom. This invokes a further level study. SBI being the leading public sector bank in India as per market capitalization does not perform well while getting compared with private sector players. In fact, its performance shows a decreasing trend. In order to check how the market has perceived these banks, we conducted a comparative study based on PB ratio. Here also we see better performance of the private banks than the public sector banks. Similar to their financial performances, IndusInd Bank, Kotak Mahindra Bank and HDFC bank consistently share top three positions while contrary to financial performance, SBI performs relatively better at market. This is probably because it had relatively better spread across the country and as per the consumer perception; it is a trustable PSU in the country. But, still its performance as compared to private sector banks under study is not satisfactory. Figure 2 and 3 also reveal the same fact that over a five year span, private sector banks have performed better than public sector banks as far as stock price movement is concerned. Next, when we perform K-means clustering to check the relative efficiency of the banks under study in managing their assets, specifically NPA; it reveals private sector banks are more efficient than public sector banks. Public sector banks mostly find their places in cluster 2 (Average) along with private bank while cluster 1(Efficient) 
consists of only private sector banks and cluster 3 (Poor) is constituted with only public sector banks. Therefore, our propositions before the study are supported by the findings.

\section{Limitations and future scope of research}

In this study, we have examined the performance of the selected private and public sector banks in India based on financial ratios related to management efficiency. Further, our sample size is relatively small. In a sense, this is a small scale study. In addition, we have only considered PB ratio as an indicator of market performance. Taking this study as a base level analysis, following scope of future research may be attempted. First, we have not considered other financial ratios pertaining to capital adequacy, asset management, earnings and liquidity positions. One can incorporate these ratios into analysis and study the banks on each such dimension for understanding their relative strength and weakness. Then, one study can be made to understand which factor is predominant in differentiating banks on the basis of financial performance. Second, a granular level investigation can be made to understand market perception about these stocks. For example, opinion based mining can be explored to reveal the key factors which control the market performance of the banks. Third, Indian banks are regulated by the central authority. Therefore, it is difficult to take customized measures. Hence, an exploratory study can be made to understand the nature of NPA and reasons behind their generation. In this context, assessing the impact of macro-economic variables can be thought of. Further, an empirical research can be carried out for investigating the impact of NPA on the operational efficiency of the bank. Fourth, in our study, we have not considered any non-financial measure. Therefore, a holistic attempt can be made considering the dimensions of balanced scorecard, service quality and service performance coupled with financial measures to understand which factors are really responsible for deciding the effective performance of the banks and according appropriate performance measurement approach can be derived thereof. Fifth, an integrated study can be made wherein the relationship between various factors affecting the performance of banks is examined and subsequently predictive analysis is carried out for forecasting future performance. Sixth, technology has invaded into banking operation significantly. An attempt can be made to assess banks' readiness to accept technological change and subsequent impact on their performance. Seventh, we have considered only Indian banks - Public Sector and Private Sector. However, foreign banks can also be included in the study to examine our findings. Further, we can make cross-country (e.g. Cross country study of performance of banks of SAARC countries) study over a relatively long time horizon (e.g. 10 years). A thought provoking study may be attempted to check consistency of financial and market performance and NPA growth over three distinct periods such as pre-recession (before 2008), during recession (2008-09) and post-recession (2010 till date). Finally, CODAS is a relatively advanced distance based MCDM method. We can further examine its applications in different management decision making situations. In addition, we can examine its applicability by using different other distance measures and/or different criteria weight determination techniques or different normalization approaches. Further, one can attempt to extend the application of this method in Neutrosophic Fuzzy environment. Also an attempt may be made to check its reliability by changing the value of the threshold parameter. The method like DEA can also be applied in conjunction with CODAS in various applications.

\section{Conclusion}

In this small scale study, we have attempted to appraise the performance of selected private sector and public sector banks in India on three dimensions: financial, market and management of NPA. We have also tried to examine that whether financially better performer can perform well in the market and whether efficient NPA management has any relationship with financial performance. We have applied MCDM technique such as CODAS for assessing financial performance based on mainly management efficiency ratios and k-means clustering for understanding and grouping the banks as per their NPA management. We have ranked the banks based on PB ratio, as an indicator of market performance. We have also examined stock price movements of the banks under study. Our findings conform to the proposition like the bank, which perform well financially, delivers efficient NPA management and gets 
perceived well in the market place. Further, we have observed that private sector banks perform better than public sector banks on all three above mentioned dimensions. As per our understanding we have listed a few areas for future research based on our study. For development of the economy, banks play a very crucial role and over last few decades dynamic changes have been taking place in the global economy. Therefore, it is essential to study the performance of banks. Hence, we hope that our study shall add value to the growing literature.

\section{Acknowledgement}

The authors would like to express their sincere gratitude to all anonymous referees for their patient review and valuable remarks.

\section{References}

Abbott, M., Wu, S., \& Wang, W. (2013). The productivity and performance of Australia's major banks since deregulate. Journal of Economics \& Finance, 37(1), 122- 135.

Akkoç, S., \& Vatansever, K. (2013). Fuzzy performance evaluation with AHP and TOPSIS methods: Evidence from Turkish banking sector after the global financial crisis. Eurasian Journal of Business and Economics, 6 (11), 53-74.

Albayrak, E., \& Erensal, Y. C. (2005). A study bank selection decision in Turkey using the extended fuzzy AHP method. In 35th International conference on computers and industrial engineering, Istanbul, Turkey.

Altman, I. E. (1968). Financial ratios, discriminant analysis and prediction of corporate bankruptcy. Journal of Finance, 23(4), 589-609.

Amile, M., Sedaghat, M., \& Poorhossein, M. (2013).Performance evaluation of banks using fuzzy AHP and TOPSIS case study: state-owned banks, partially private and private banks In Iran. Caspian Journal of Applied Sciences Research, 3, 128-138.

Amirzadeh, R., \& Shoorvarzy, M.R. (2013). Prioritizing service quality factors in Iranian Islamic banking using a fuzzy approach. International Journal of Islamic and Middle Eastern Finance and Management, 6(1), 6478.

Avkiran, N. K. (2010). Association of DEA super-efficiency estimates with financial ratios: Investigating the case for Chinese banks. Omega, 39(3), 323-334. https://doi.org/10.1016/j.omega.2010.08.001

Ayadi, O.F., Adebayo, A. O., \& Omolehinwa, E. (1998). Bank performance measurement in a developing economy: An application of data envelopment analysis. Managerial Finance, 24(7), 5-16.

Baležentis, A., Baležentis, T., \& Misiunas, A. (2012). An integrated assessment of Lithuanian economic sectors based on financial ratios and fuzzy mcdm methods. Technological and Economic Development of Economy, 18(1), 34-53.

Bayyurt, N. (2013). Ownership effect on bank's performance: Multi criteria decision making approaches on foreign and domestic Turkish banks. Procedia - Social and Behavioral Sciences 99, 919 - 928. https://doi.org/10.1016/j.sbspro.2013.10.565

Beaver, W. H. (1966). Financial ratios as predictors of failure. Journal of Accounting Research, 5, 71-111.

Beaver, W. H. (1968). Market prices, financial ratios, and the prediction of failure. Journal of Accounting Research, 6(2), 179-192.

Bhattacharyay, B.N. (2011). Macro-prudential monitoring of financial crisis: An empirical framework. in Chatterji, M., Gopal, D., and Singh, S. (eds.) Governance, Development and Conflict (Contributions to Conflict Management, Peace Economics and Development, Emerald Group Publishing Limited, 18, 71-121.

Celen, A. (2014). Evaluating the financial performance of Turkish banking sector: A fuzzy medm approach. Journal of Economic Cooperation and Development, 35(2), 43-70.

Chatterjee, D., Chowdhury, S., \& Mukherjee, B. (2010). A study of the application of fuzzy analytical hierarchical process (FAHP) in the ranking of Indian banks. International Journal of Engineering Science and Technology, 7, 2511-2520.

Dash, M., \& Das, A. (2013). Performance appraisal of Indian banks using CAMELS rating. IUP Journal of Bank Management, 12(2), 31-42.

Dash, M., \& Charles, C. (2012). An Analysis of the technical efficiency of banks in India. IUP Journal of Bank Management, 11(4), 100-109.

Dash, M., \& Vegesna, S. (2014). Efficiency of public and private sector banks in India. Journal of Applied Management and Investments, 3(3), 183-187. 
Datta Chaudhuri, T., \& Ghosh, I. (2015). Application of multi-criteria decision making models in regulatory evaluation of commercial banks in India and its consistency with public perception. Available at SSRN: https://ssrn.com/abstract=2546647 or http://dx.doi.org/10.2139/ssrn.2546647

De young, R., Flannery, M.J., Lang, W.W., \& Sorescu, S.M. (2001). The information content of bank exam ratings and subordinated debt prices. Journal of Money, Credit and Banking, 33 (4), 900-925.

Doumpos, M., \& Zopounidis, C. (2015). A multicriteria approach to bank rating. In Bisdorf, R., Dias (eds), Evaluation and Decision Models with Multiple Criteria (pp. 563-587). Springer, Berlin, Heidelberg.

Doumpos, M., \& Zopounidis, C. (2013). Efficiency and performance evaluation of European cooperative banks. in Efficiency and Productivity Growth: Modelling in the Financial Services Industry, ed. Pasiouras, F., John Wiley \& Sons, Ltd, Chichester, UK.

Faber, V. (1994). Clustering and the continuous k-means algorithm. Los Alamos Science, 22(138144.21).

Fallah, M., Aryanezhadb, M.B., Najafi, S.E., \& Shahsavaripour, N. (2011). An empirical study on measuring the relative efficiency using DEA method: A case study of bank industry. Management Science Letters, 1(1), 49-56. https://doi.org/10.5267/j.msl.2010.01.005

Fairfield, P. M. (1994). P/E, P/B and the present value of future dividends. Financial Analysts Journal, 50(4), 23-31.

Foster, E. M. (1970). Price-Earnings Ratio and corporate growth. Financial Analysts Journal, 26(1), 96-99.

Ghorabaee, M.K., Zavadskas, E.K., Turskis, Z., \& Antucheviciene, J. (2016). A new combinative distance-based assessment (CODAS) method for multi-criteria decision-making. Economic Computation and Economic Cybernetics Studies and Research, 50(3), 25-41.

Ginevičius, R., \& Podviezko, A. (2013). The evaluation of financial stability and soundness of lithuanian banks. Ekonomska Istraživanja-Economic Researc, 26(2), 191-208.

Gowri, C.A., \& Malepati, V. (2017). Evaluation of financial performance of selected banks. Decision, 44(1), 314.

Grigoroudis, E., Tsitsiridi, E., \& Zopounidis, C. (2013). Linking customer satisfaction, employee appraisal, and business performance: An evaluation methodology in the banking sector. Annals of Operations Research, 205(1), 5-27.

Gupta, R. (2008). A CAMEL model analysis of private sector banks in India. Journal of Gyan Management, 2(1), 3-8.

Halkos, G., \& Salamouris, D. (2004). Efficiency measurement of Greek commercial banks with the use of financial ratios: A Data Envelopment Analysis approach. Management Account Research 15, 201-224. https://doi.org/10.1016/j.mar.2004.02.001

Hays, F. H., De Lurgio, S. A., \& Gilbert, A. H. (2009). Efficiency ratios and community bank performance. Journal of Finance and Accountancy, 1, 1-15.

Ho, C.B., \& Wu, D.D. (2009). Online banking performance evaluation using data envelopment analysis and principal component analysis. Computers \& Operations Research, 36, 1835-1842

Kao, C., \& Liu, S.-T. (2004). Predicting bank performance with financial forecasts: A case of Taiwan commercial banks. Journal of Banking and Finance, 28(10), 2353-2368. https://doi.org/10.1016/j.jbankfin.2003.09.008

Kaplan, R. S., \& Norton, D. P. (1996). The Balanced Scorecard: Translating Strategy into Action. Harvard Business Press.

Klomp, J., \& de Haan, J. (2011). Banking risk and regulation: Does one size fit all? DNB Working Paper No.323, available at: http://papers.ssrn.com/sol3/papers.cfm?abstract id=197723.

Kumar, P.R., \& Ravi, V. (2007). Bankruptcy prediction in banks and firms via statistical and intelligent techniques: a review. European Journal of Operational Research, 180 (1), 1-28.

Kwan, S., \& Eisenbeis, R. A. (1997). Bank risk, capitalization, and operating efficiency. Journal of Financial Services Research, 12(2/3), 117-131.

Li, X., Wang, K., Liu, L., Xin, J., Yang, H., \& Gao, C. (2011). Application of the entropy weight and TOPSIS method in safety evaluation of coal mines. Procedia Engineering, 26, 2085-2091.

Maishanu, M. M. (2004). A univariate approach to predicting failure in the commercial banking sub-sector. Nigerian Journal of Accounting Research, 1(1), 70-84.

Maliszewski, K. (2009). Measuring Stability of the Polish financial system by means of a synthetic index. Presented at the 12th International Conference on Finance and Banking, held on Oct. 28-29, 2009, organised by Silesian University in Opava.

Marie, A., Al-Nasser, A., \& brahim, M. (2013). Operational-profitability-quality performance of Dubai's banks. Journal of Management Research, 13(1), 25-34. 
Minh, N. K., Long, G. T., \& Hung, N. V. (2013). Efficiency and super-efficiency of commercial banks in Vietnam: Performances and determinants. Asia-Pacific Journal of Operational Research, 30(1), 1- 19.

Momeni, M., Maleki, M. H., Afshari, M. A., Moradi, J. S., \& Mohammadi, J. (2011). A fuzzy MCDM approach for evaluating listed private banks in Tehran stock exchange based on balanced scorecard. International Journal of Business Administration, 2(1), 80-97.

Mous, L. (2005). Predicting bankruptcy with discriminant analysis and decision tree using financial ratios. Working Paper Series, University of Rotterdam.

Njoku, J. (2011). Anatomic assessment of CAMEL in Nigerian banking. International Journal of Economics and Accounting, 2(1), 76-99. https://doi.org/10.1504/IJEA.2011.038964

Njoku, J., \& Inanga, E.L. (2012). Underlying nature of the 2008-2009 banking crises. African Journal of Accounting, Auditing and Finance, 1(2), 190-208.

Ohlson, J. A. (2001). Earnings, book values, and dividends in equity valuation: An empirical perspective. Contemporary accounting research, 18(1), 107-120.

Önder, E., \& Hepşen, A. (2013). Combining time series analysis and multi criteria decision making techniques for forecasting financial performance of banks in turkey. International Journal of Latest Trends in Financial \& Economic Sciences, 3(3), 530-555.

Pal, M., \& Choudhury, K. (2009). Exploring the dimensionality of service quality: An application of TOPSIS in the Indian banking industry. Asia-Pacific Journal of Operational Research, 26(1), 115- 133

Penman, S. H. (1996). The articulation of price-earnings ratios and market-to-book ratios and the evaluation of growth. Journal of accounting research, 235-259.

Poghosyan, T., \& Cihák, M. (2011). Distress in European banks: an analysis based on a new dataset. Journal of Financial Services Research, 40 (3), 163-184.

Popovska, J. (2014). Modelling financial stability: The case of the banking sector in Macedonia. Journal of Applied Economics and Business, 2(1), 68-91.

Said, M., \& Saucier, P. (2003). Liquidity, solvency, and efficiency: An empirical analysis of the Japanese banks' distress. Journal of Oxford, 5(3), 354-358.

Samir, D., \& Kamra, D. (2013). A comparative analysis of non-performing assets (NPAs) of selected commercial banks in india. Opinion: International Journal of Management, 3(1), 68-80. Available at SSRN: https://ssrn.com/abstract $=2629587$

Sarker, A. (2005). CAMELS rating system in the context of islamic banking: A proposed ' $S$ ' for Shariah framework. Journal of Islamic Economics and Finance, 1(1), 78-84.

Sayed, G. J., \& Sayed, N. S. (2013). Comparative analysis of four private sector banks as per CAMEL rating. Business Perspectives \& Research, 1(2), 31-46.

Shannon, C.E. (1948). The mathematical theory of communication. Bell System Technical Journal, 27, 379-423

Shaverdi, M., Akbari, M., \& Tafti, S.F. (2011). Combining fuzzy MCDM with BSC approach in performance evaluation of Iranian private banking sector. Advances in Fuzzy Systems, 12, 12-27

Stankevičienè, J., \& Mencaite, E. (2012). The evaluation of bank performance using a multicriteria decision making model: a case study on Lithuanian commercial banks. Technological and Economic Development of Economy, 18(1), 189-205

Toloie-Eshlaghy, A., Ghafelehbashi, S., \& Alaghebandha, M. (2011). An investigation and ranking public and private islamic banks using dimension of service quality (SERVQUAL) based on TOPSIS fuzzy technique. Applied Mathematical Sciences, 5, 3031 - 3049.

Wu, H.Y., Tzeng, G.H., \& Chen, Y.H. (2009). A fuzzy MCDM approach for evaluating banking performance based on balanced scorecard. Expert Systems with Applications, 36, 10135-10147

www.moneycontrol.com

www.rbi.org.in

www.corporatefinanceinstitute.com

https://www.valueresearchonline.com

https://www.morningstar.in/

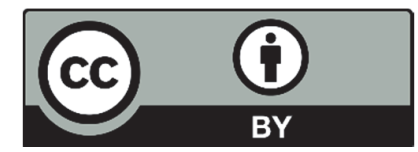

(C) 2019 by the authors; licensee Growing Science, Canada. This is an open access article distributed under the terms and conditions of the Creative Commons Attribution (CC-BY) license (http://creativecommons.org/licenses/by/4.0/). 